\title{
Gonadal dysfunction after treatment of intracranial tumours
}

\author{
E A LIVESEY AND C G D BROOK
}

\author{
Endocrine Unit, Middlesex Hospital, London
}

SUMmARY Ninety three children (51 boys, 42 girls) who had been treated for brain tumours not affecting the hypothalamopituitary axis, were studied for evidence of gonadal dysfunction. All had received cranial irradiation, 59 spinal irradiation, and 28 adjuvant chemotherapy. Mean age at treatment was $6 \cdot 3$ years (range $1 \cdot 5-15$ ). Mean follow up after completion of radiotherapy was 8.5 years (range 1-27). Primary ovarian damage occurred in seven out of $11(64 \%)$ girls treated with craniospinal irradiation alone and in nine out of $14(64 \%)$ of those treated with craniospinal irradiation and chemotherapy. The association with spinal irradiation was significant. Primary gonadal damage also occurred in three out of four children treated with chemotherapy combined with cranial irradiation and in three out of nine boys treated with chemotherapy and craniospinal irradiation but in no boy given craniospinal irradiation alone. The only common chemotherapeutic agent was a nitrosurea. Hypogonadotrophic hypogonadism was found in seven boys, $5 \cdot 8 \%$ of children of pubertal age.

Primary gonadal dysfunction is a well known complication of the treatment of some childhood malignancies, particularly leukaemia and lymphoma. ${ }^{1-8}$ The prevalence and aetiology of gonadal dysfunction after treatment of brain tumours in childhood are unclear; this is because reported series are relatively small and because of differences in treatment. Most authors have attributed gonadal damage to scatter from spinal irradiation ${ }^{910}$ but more recently Ahmed et al concluded that adjuvant chemotherapy was responsible. ${ }^{11}$ Brown et al also referred to girls with primary ovarian damage after treatment with lomustine (CCNU) without spinal irradiation. ${ }^{10}$ Three affected girls with ovarian damage attributed to spinal irradiation, described by Rappaport et al, had also received chemotherapy.

Gonadal dysfunction can also be secondary to gonadotrophin deficiency caused by cranial irradiation ${ }^{12}$ but there are few data on the incidence after the treatment of childhood brain tumours. Rappaport et al reported that gonadotrophin deficiency may occur infrequently in these patients. $^{9}$

We have studied the aetiology and prevalence of primary and secondary gondal dysfunction in a large cohort of children treated for brain tumours.

\section{Patients and methods}

Altogether 125 children who were in clinical remission after receiving radiotherapy for brain tumours not affecting the hypothalamopituitary region were studied. Information about gonadal function is reported for 93 of them ( 51 boys, 42 girls). The remaining 32 children were still prepubertal with serum gonadotrophin concentrations appropriate for age. They were not included in the analysis because hypogonadotrophic gonadal dysfunction cannot be excluded until they reach puberty. ${ }^{13}$ The mean age of the 93 children at treatment was 6.3 years (range 1.5-15) and mean follow up since completion of radiotherapy 8.5 years (range 1-27). Eighty one children were prepubertal when treated, 86 children ( 48 boys, 38 girls) were of pubertal age when studied. The diagnosis was medulloblastoma in 37 children, astrocytoma in 26 , glioma in five, ependymoma in 11, pineal germinoma in eight, optic nerve glioma in four, with one ganglioglioma and one meningioma.

After surgery in most children, megavoltage cranial irradiation using either a $5 \mathrm{MeV}$ linear accelerator $(n=46)$ or cobalt 60 source $(n=47)$ was given to a calculated median hypothalamic dose of $47 \mathrm{~Gy}(40-55)$ in 34 fractions (range $30-40$ ) over 49 
days (range 30-99). Fifty six children also received spinal irradiation using a direct open field to S2-S3 with a median dose of 32 Gy (range 29-33) in 25 fractions (range 20-30) over 43 days (range 30-91). Twenty eight children received adjuvant chemotherapy. The cytotoxic agents given were: intravenous lomustine $340-1200 \mathrm{mg} / \mathrm{m}^{2}$, vincristine 4-51 $\mathrm{mg} / \mathrm{m}^{2}$, and methotrexate $2-4.5 \mathrm{~g} / \mathrm{m}^{2}$ singly or in different combinations. Lomustine and vincristine were generally given according to International Society of Paediatric Oncology (SIOP) schedules. ${ }^{14}$

Primary gonadal dysfunction and gonadotrophin deficiency were identified by clinical assessment of puberty and measurements of basal serum gonadotrophin concentrations and, in most, peak responses to intravenous gonadotrophin releasing hormone $100 \mu \mathrm{g}$. Statistical analyses were made by $\chi^{2}$ and the Mann-Whitney tests.

\section{Results}

\section{PRIMARY OVARIAN DYSFUNCTION}

Eighteen of 42 girls $(43 \%)$ had evidence of primary ovarian dysfunction as judged by raised basal serum gonadotrophin concentrations (table 1). There was a significant association between craniospinal irradiation and primary ovarian dysfunction $(\mathrm{p}<0 \cdot 01)$, but the addition of chemotherapy to craniospinal irradiation did not increase the incidence significantly. In girls not given spinal irradiation, however,

Table 1 Incidence of primary gonadal dysfunction according to treatment

\begin{tabular}{lllll}
\hline & \multicolumn{2}{l}{ Ovarian dysfunction } & & Testicular dysfunction \\
\cline { 2 - 5 } & $\begin{array}{l}\text { Without } \\
\text { chemotherapy }\end{array}$ & $\begin{array}{l}\text { With } \\
\text { chemotherapy }\end{array}$ & $\begin{array}{l}\text { Without } \\
\text { chemotherapy }\end{array}$ & $\begin{array}{c}\text { With } \\
\text { chemotherapy }\end{array}$ \\
\hline Cranial irradiation & $0 / 14$ & $2 / 3$ & $0 / 15$ & $1 / 1$ \\
Craniospinal irradiation & $7 / 11$ & $9 / 14$ & $0 / 16$ & $3 / 9$ \\
\hline
\end{tabular}

Table 2 Clinical details of girls with primary ovarian dysfunction $(n=18)$

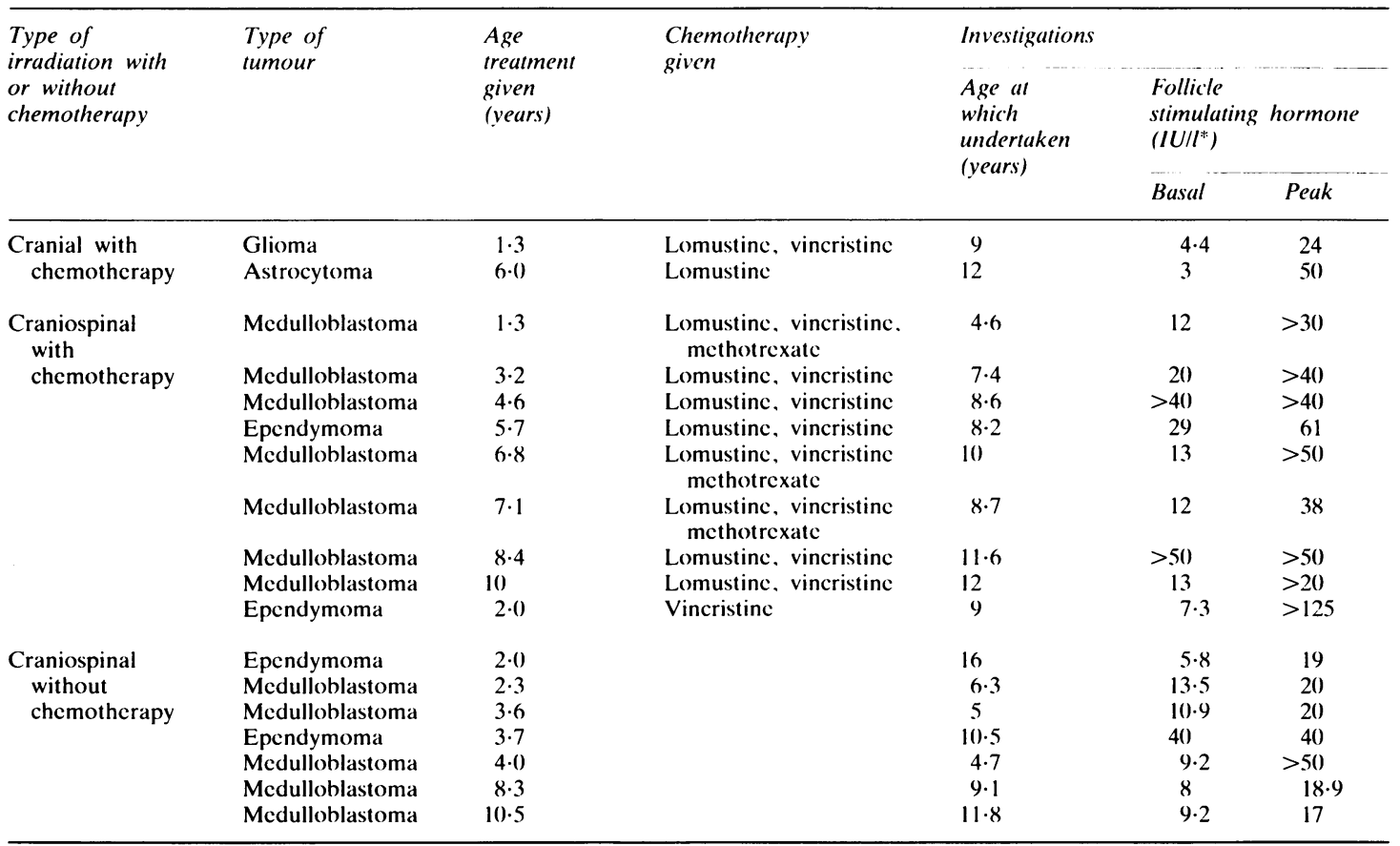

*Normal concentration follicle stimulating hormone: basal, $<3$ IU/l: peak prepubertal, $5 \cdot 8$ IU/l; peak pubertal, $6 \cdot 21$ IU/l. †Normal concentration luteinising hormone: basal, $<3$ IU/l; peak prepubertal, $7 \cdot 1$ IU/l; peak pubertal $18 \cdot 2$ IU/I. $\ddagger \mathrm{B}=$ breast stage development according to Tanner. 
chemotherapy made a significant contribution to subsequent ovarian dysfunction $(p<0.02)$; lomustine was common to those with ovarian damage. There was no relation between doses, duration, or timing of cytotoxic agents and presence of damage. There was also no relation between the type of radiotherapy source, cobalt 60 or linear accelerator, and the incidence of ovarian damage, although the cobalt 60 source has a wider penumbra. Affected girls were significantly younger at treatment (age 5.7 year $v 7.0$ years $)(p<0 \cdot 05)$. Transiently raised serum follicle stimulating hormone and luteinising hormone concentrations detected in two prepubertal girls within 0.7 years of completing spinal irradiation had returned to normal within 1.8 years. The pubertal development of affected girls was variable as shown in table 2 .

\section{PRIMARY TESTICULAR DYSFUNCTION}

Four of 44 boys $(9 \%)$ had raised basal and peak serum follicle stimulating hormone concentrations and two had raised luteinising hormone concentrations. All had received chemotherapy (table 3 ). The association with chemotherapy was significant $(p<0 \cdot 02)$, but there were no differences in dose or duration of chemotherapy between them and those unaffected. Two of the four boys made normal pubertal progress but had final testicular volumes of less than $12 \mathrm{ml}$; sperm counts were not obtained. Puberty arrested in one boy at 14 years and he was treated with testosterone. The fourth boy was of prepubertal age.

It is possible that a boy could have primary testicular dysfunction and be gonadotrophin deficient and the former would not be detected by gonadotrophin concentrations. Boys with gonadotrophin deficiency have therefore been excluded from the analysis of primary testicular dysfunction.

\section{GONADOTROPHIN DEFICIENCY}

Delayed ( $>2$ SD) or arrested ( $>18$ months) puberty were rare in the 86 children of pubertal age. There were five affected boys, with low basal and peak serum concentrations of follicle stimulating hormone and low or normal concentrations of luteinising hormone (table 4). Two had pineal tumours, which can interfere with gonadotrophin secretion, suggesting that the true prevalence of treatment

\begin{tabular}{|c|c|c|c|c|}
\hline $\begin{array}{l}\text { Lutenising } \\
\text { hormone } \\
(I U / l) \dagger\end{array}$ & & $\begin{array}{l}\text { Onset } \\
\text { of puberty } \\
\text { (years) }\end{array}$ & $\begin{array}{l}\text { Progress } \\
\text { of puberty } \neq \\
\text { (age in years) }\end{array}$ & $\begin{array}{l}\text { Oestrogen } \\
\text { treatment } \\
\text { (age in years) }\end{array}$ \\
\hline Basal & Peak & & & \\
\hline 66 & 99 & 16 & Arrested B2 (17.0) & $17 \cdot 0$ \\
\hline 6 & 70 & 12 & Arrested B3 (13.6) & $13 \cdot 6$ \\
\hline 1 & $8 \cdot 2$ & Prepubertal & & \\
\hline 1 & 29 & 9 & Arrested B3 (13.5) & $13 \cdot 5$ \\
\hline 33 & $>100$ & 9 & Arrested B3 (11.4) & $11 \cdot 4$ \\
\hline 34 & $>100$ & $10 \cdot 7$ & Menarche $(12 \cdot 5)$ & \\
\hline $8 \cdot 9$ & $>50$ & Prepubertal & & \\
\hline$<1$ & 13 & $10 \cdot 9$ & Arrested B2 (12.2) & $12 \cdot 2$ \\
\hline 31 & $>100$ & $13 \cdot 5$ & B4 (15.0) & \\
\hline $2 \cdot 7$ & $>35$ & 11 & B3 $(12.9)$ & \\
\hline 11 & $>100$ & 12 & Amenorrhea B5 (17) & \\
\hline $21 \cdot 6$ & $>40$ & 9 & Menarche (11) & \\
\hline $1 \cdot 5$ & 6 & Prepubertal & & \\
\hline $1 \cdot 3$ & 13 & Prepubertal & & \\
\hline 24 & 86 & 10 & Arrested B4 (12.5) & $12 \cdot 5$ \\
\hline $3 \cdot 8$ & $13 \cdot 7$ & Prepubertal & & \\
\hline $1 \cdot 6$ & $6 \cdot 3$ & $10 \cdot 3$ & Arrested B3 (13·1) & \\
\hline $3 \cdot 2$ & 10 & $13 \cdot 1$ & B4 (14.0) & \\
\hline
\end{tabular}


Table 3 Clinical details of boys with primary testicular dysfunction $(n=4)$

\begin{tabular}{|c|c|c|c|c|}
\hline $\begin{array}{l}\text { Type of } \\
\text { irradiation }\end{array}$ & $\begin{array}{l}\text { Type } \\
\text { of } \\
\text { tumour }\end{array}$ & $\begin{array}{l}\text { Age } \\
\text { radiotherapy } \\
\text { given } \\
\text { (years) }\end{array}$ & $\begin{array}{l}\text { Chemotherapy } \\
\text { given }\end{array}$ & $\begin{array}{l}\text { Investigations } \\
\text { Age at which } \\
\text { undertaken } \\
\text { (years) }\end{array}$ \\
\hline Cranial & Astrocytoma & 4 & Lomustine & 9 \\
\hline \multirow[t]{3}{*}{ Craniospinal } & Medulloblastoma & $12 \cdot 3$ & $\begin{array}{l}\text { Lomustine, } \\
\text { vincristine }\end{array}$ & 19 \\
\hline & Medulloblastoma & 14 & $\begin{array}{l}\text { Lomustinc, } \\
\text { vincristine }\end{array}$ & 29 \\
\hline & Medulloblastoma & $5 \cdot 8$ & $\begin{array}{l}\text { Lomustine, } \\
\text { vincristine }\end{array}$ & 11 \\
\hline
\end{tabular}

${ }^{*}$ Normal concentration follicle stimulating hormone: basal, $<3 \mathrm{IU} / \mathrm{I}$; peak prepubertal, $5 \cdot 8 \mathrm{IU} / \mathrm{l}$; peak pubertal, $6 \cdot 2 \mathrm{IU} / \mathrm{l}$.

†Normal concentration luteinising hormone: basal, $<3$ IU/l; peak prepubertal, $7 \cdot 1$ IU/l; peak pubertal, $18 \cdot 2$ IU/l.

Table 4 Clinical details of boys with gonadotrophin deficiency $(n=5)$

\begin{tabular}{|c|c|c|c|c|}
\hline $\begin{array}{l}\text { Type } \\
\text { of } \\
\text { tumour }\end{array}$ & $\begin{array}{l}\text { Age } \\
\text { radiotherapy } \\
\text { given } \\
\text { (years) }\end{array}$ & $\begin{array}{l}\text { Radiation dose } \\
\text { to } \\
\text { hypothalamus } \\
\text { (Gy) }\end{array}$ & $\begin{array}{l}\text { Investigations } \\
\text { Age } \\
\text { at which } \\
\text { undertaken } \\
\text { (years) }\end{array}$ & $\begin{array}{l}\text { Pubertal } \\
\text { stage }^{*}\end{array}$ \\
\hline Medulloblastoma & 5 & 52 & 9 & $1 / 1 / 1 \quad 2 / 2$ \\
\hline Astrocytoma & 14 & 54 & 17 & $2 / 1 / 1 \quad 4 / 4$ \\
\hline Medulloblastoma & 8 & 45 & 12 & $1 / 1 / 1 \quad 2 / 2$ \\
\hline Pinealoma & 14 & 45 & 17 & $1 / 1 / 1 \quad 2 / 2$ \\
\hline Pinealoma & 11 & 48 & 11 & $1 / 1 / 12 / 2$ \\
\hline
\end{tabular}

"Puberty ratings, according to Tanner. ${ }^{19}$ given as genitals/pubic hair/axillary hair with testicular volumes in ml.

related gonadotrophin deficiency may be even lower. No girl was affected. There was no difference in hypothalamopituitary irradiation between the affected and unaffected children. Two girls had transient amenorrhoea but normal basal and peak serum gonadotrophin concentrations. Of these one had secondary amenorrhoea lasting 13 months and the other, who had been treated at 9 years, reached menarche at the age of 17 years.

\section{Discussion}

We have shown that spinal irradiation and chemotherapy may each cause primary gonadal dysfunction separately in a substantial number of children treated for brain tumours remote from the hypothalamus or pituitary. Spinal irradiation was the dominant gonadotoxic treatment. This is shown by the preponderance of ovarian dysfunction when comparing boys and girls treated with spinal irradiation and chemotherapy and the failure of chemotherapy to affect the prevalence of ovarian dysfunction in these girls. The relatively few studies of ovarian function after abdominal or spinal irradiation in childhood show that ovaries are vulnerable to damage at any age. ${ }^{25}$ Our data support this but show an increased prevalance among younger girls, which may indicate that the ovary is more vulnerable but which is more probably due to the greater mobility of the ovarian position in relation to the spinal field.

Ovarian dysfunction was not a consistent complication of spinal irradiation, as others have shown. ${ }^{9-11}$ The likely explanation is provided by serial pelvic ultrasound scans that show that ovaries move frequently, particularly in a lateral plane $(\mathrm{J}$ Adams, Middlesex Hospital, personal communication). This observation may have implications for the prevention of ovarian damage, suggesting that only adequate surgical transposition (oophoropexy) will reduce the incidence of radiation induced damage. Oophoropexy has been shown to reduce the incidence of amenorrhoea in adult women after irradiation for Hodgkin's disease. ${ }^{15}$ The uncertainty 


\begin{tabular}{|c|c|c|c|c|c|}
\hline \multicolumn{2}{|c|}{$\begin{array}{l}\text { Follicle stimulating } \\
\text { hormone (IU/l) }\end{array}$} & \multicolumn{2}{|c|}{$\begin{array}{l}\text { Luetinsing } \\
\text { hormone (IU/l) }\end{array}$} & \multirow[t]{2}{*}{$\begin{array}{l}\text { Onset } \\
\text { of puberty } \\
\text { (years) }\end{array}$} & \multirow[t]{2}{*}{$\begin{array}{l}\text { Outcome } \\
\text { (testicular volumes } \\
\text { in } \mathrm{ml} \text { ) }\end{array}$} \\
\hline Basal & Peak & Basal & Peak & & \\
\hline $9 \cdot 7$ & 20 & 1.7 & 20 & Prepubertal & \\
\hline $7 \cdot 8$ & - & $2 \cdot 5$ & - & 12 & Small testes $10 / 10$ \\
\hline$>20$ & - & $12 \cdot 5$ & - & 12 & Small testes $10 / 10$ \\
\hline 9 & 13 & 10 & 16 & 11 & Arrested $6 / 6$ at 14.6 years \\
\hline
\end{tabular}

\begin{tabular}{|c|c|c|c|c|c|c|}
\hline \multirow{2}{*}{\multicolumn{2}{|c|}{$\begin{array}{l}\text { Follicle stimulating } \\
\text { hormone }(I U / l)\end{array}$}} & \multirow{2}{*}{\multicolumn{2}{|c|}{$\begin{array}{l}\text { Luteinising } \\
\text { hormone (IU/l) }\end{array}$}} & \multirow{3}{*}{$\begin{array}{l}\text { Serum } \\
\text { testosterone } \\
\text { (nmolll) }\end{array}$} & \multicolumn{2}{|c|}{ Pubertal process } \\
\hline & & & & & \multirow[t]{2}{*}{$\begin{array}{l}\text { Age examined } \\
\text { (years) }\end{array}$} & \multirow[t]{2}{*}{$\begin{array}{l}\text { Pubertal } \\
\text { stage }\end{array}$} \\
\hline Basal & Peak & Basal & Peak & & & \\
\hline$<1$ & $<1$ & $<1$ & $2 \cdot 2$ & - & $12 \cdot 5$ & Prepubertal \\
\hline$<1$ & 1 & $<1$ & 2 & - & 18 & $2 / 1 / 1 \quad 4 / 4^{*}$ \\
\hline $1 \cdot 7$ & 3 & $1 \cdot 7$ & $4 \cdot 6$ & - & $15 \cdot 5$ & Prepubertal \\
\hline 1 & $2 \cdot 7$ & $7 \cdot 6$ & $9 \cdot 6$ & 0.7 & 17 & Prepubertal \\
\hline$<1$ & $<1$ & $4 \cdot 3$ & $8 \cdot 8$ & $<0 \cdot 6$ & 14 & Prepubertal \\
\hline
\end{tabular}

about ovarian position also means that accurate calculations or radiation to the ovaries are not possible. It seems preferable to compare the effects of known radiation doses to the spine.

The gonadotoxic effect of chemotherapy given to children with brain tumours has been recognised in very few studies. ${ }^{10} 11$ Chemotherapy tends to be given in combination with spinal irradiation so data about its independent effect are few. In this study lomustine was the only cytotoxic agent common to children with primary gonadal dysfunction not associated with spinal irradiation. This supports the conclusion of Ahmed et al ${ }^{11}$ that nitrosureas are gonadotoxic but our data indicate that the effects of spinal irradiation are more important than was suggested in that study. This may be due to the much larger number of children in our series but also possibly to the differences in spinal irradiation techniques used. In the Manchester study of Ahmed et al, the spinal radiation beam was directed medially towards the spine while in our patients the beam was perpendicular to the skin. There were no differences in fractionation. If these differences in outcome are substantiated, modifications in radiation technique might be justified.

There is controversy about the sensitivity of prepubertal gonads to damage by chemotherapy $^{3516}$ and the relative sensitivity of testes and ovaries to damage by chemotherapy or radiotherapy. ${ }^{17}$ Few children received chemotherapy alone but the affected girls were prepubertal, and there were equal numbers of affected prepubertal and pubertal boys.

Gonadotrophin deficiency not explained by the tumour site was rare at the median follow up of 8.5 years. Hypopituitarism is known to evolve up to 10 years after similar doses of irradiation for pituitary tumours, $(40-50 \mathrm{~Gy}),{ }^{18}$ so ours may be an underestimate. No relation with radiation dose was seen but the dose range was relatively narrow.

This is the largest reported study of gonadal dysfunction in this group of patients and shows that primary gonadal dysfunction was not uncommon particularly after gonadal radiation or certain cytotoxics whereas secondary gonadal dysfunction was rare. Long term endocrine follow up of these 
children is clearly required of the centres treating them. As survival improves the complications of treatment are found more often and should be considered when devising new treatment regimens.

We thank the Cancer Research Campaign for financial support and Drs HJG Bloom, N Godlec, and J Tobias for access to their records at the Royal Marsden and University College Hospitals and Drs AC Whitton and $\mathbf{J}$ Britton for their help.

\section{References}

1 Siris ES, Leventhal BG, Vaitukaitis JL. Effects of childhood leukaemia and chemotherapy on pubcrty and reproductive function in girls. $N$ Engl $J$ Med 1976;294:1143-6.

2 Shalet SM, Beardwell CG, Morris Jones PJ, Pearson D. Orrell DH. Ovarian failure following abdominal irradiation in childhood. Br J Cancer 1976;33:655-8.

${ }^{3}$ Himelstein-Braw R, Peters H, Faber M. Morphological study of the ovaries of leukaemic children. Br J Cancer 1978:38:82-7.

${ }^{4}$ London M, Kann IM, Palmer MR, Shalet SM, Morris Jones P. Testicular histology after combination chemotherapy in childhood for acute lymphoblastic lcukaemia. Lancet 1978;ii:439-41.

5 Stillman RJ, Schinfield JS, Schiff I, et al. Ovarian failurc in long term survivors of childhood malignancy. Am J Obstet Gynecol 1981:139:62-6.

${ }^{6}$ Whitehead E, Shalet SM, Morris Jones PJ, Bcardwell CG, Deakin DP. Gonadal function after combination chemotherapy for Hodgkin's disease in childhood. Arch Dis Child 1982;47:287-91.

7 Brauner R, Czernichow P, Cramer P, Schaison G, Rappaport R. Leydig cell function in children after direct testicular irradiation for acute lymophoblastic Icukacmia. $N$ Engl J Med 1983;309:25-8.

× Leiper AD, Grant DB, Chessells JM. Gonadal function after testicular radiation for acute lymphoblastic leukacmia. Arch Dis Child 1986;61:53-6.
"Rappaport R, Brauner R, Czernichow P, et al. Effect of hypothalamic and pituitary irradiation on pubertal development in children with cranial tumours. J Clin Endocrinol Metab 1982:54:1164-8.

10 Brown IH, Lee TJ, Eden OB, Bullimore JA, Savage DCL. Growth and endocrine function after treatment for medulloblastoma. Arch Dis Child 1983:58:722-7.

11 Ahmed SR. Shalet SM, Campbell RHA, Deakin DP. Primary gonadal damage following treatment of brain tumours in childhood. J Pediatr 1983;103:562-5.

12 Samaan NA, Maor M, Sampicre VA, Cangir A, Jesse RH. Hypopituitarism after external irradiation and nasopharyngeal cancer. In: Linfoot JA, ed. Recent advances in the diagnosis and treatment of pituitary tumours. New York: Raven Press, 1979: $315-30$.

13 Winter JDS, Faiman C, Reyes FI, Hobson WC. Gonadotrophins and steroid hormone in the blood and urine of prepubertal girls and other primates. Clin Endocrinol Metab 1978;7:513-30.

14 Bloom HJG. Tumours of the CNS. In: Voute PA, Barrett A, Bloom HJG, Lemerle J, Neidhardt MK, eds. Cancer in children, clinical management. 2nd ed. Basel: Springer Verlag 1986: 197-222.

15 Baker JW, Morgan RL, Peckham MJ, Smithers DW. Preservation of ovarian function in patients requiring radiotherapy for paraaortic and pelvic Hodgkin's disease. Lancet 1972;i:1307-8.

16 Matus-Ridlcy M, Nicosia SV. Meadows A. Gonadal effects of cancer therapy in boys. Cancer 1985;55:2353-63.

17 Shalet SM. Disorders of the endocrine system due to radiation and cytotoxic chemotherapy. Clin Endocrinol $(O X F)$ 1983:18:637-59.

${ }^{1 \times}$ Eastman RC, Gordon P, Roth J. Conventional supervoltage irradiation is an effective treatment for acromegaly. J Clin Endocrinol Metab 1979;48:931-40.

19 Tanner JM. Growth at adolescence. 2nd ed. Oxford: Blackwell Scientific Publications, 1966.

Correspondence to Dr CGD Brook, Endocrine Unit, Middlesex Hospital, Mortimer Strect, London WIN 8AA.

Accepted 26 November 1987 